\title{
Ulsan, South Korea: A Global and Nested 'Great' Industrial City
}

\author{
A.J. Jacobs ${ }^{*}$
}

Department of Sociology, East Carolina University, 405A Brewster, MS 567, Greenville, NC 27858, USA

\begin{abstract}
Ulsan, South Korea is home to the world's largest auto production complex and shipyard, and its second biggest petrochemicals combine. Drawing upon Jacobs' Contextualized Model of Urban-Regional Development, this article shows how Ulsan's growth path towards becoming one of the world's Great Industrial Cities was decisively shaped by both global and nested factors. While the weights of the various tiers from the global to local have fluctuated over time, no one level has had primacy. Through Ulsan this study seeks to introduce the concept of Great Industrial City and in the process: 1) remind scholars and practitioners about the continued importance of industrial cities for national economies and in global capitalism; 2) demonstrate how the world's city-regions have been decisively shaped by both international forces and embedded/nested factors; 3) enhance the English language reader's knowledge of South Korean urban areas; and 4) encourage scholars to more seriously consider the manufacturing sector when classifying world cities and delineating the global urban hierarchy, and thereby, expand the global-nested city debate beyond merely the analyzing of large financial centers.
\end{abstract}

Keywords: Great industrial cities, Ulsan, South Korean cities, Global city, Nested city theory.

\section{INTRODUCTION}

Ulsan, South Korea is home to the world's largest auto production complex and fifth largest automaker, its biggest shipyard and shipbuilder, and the globe's second largest petrochemicals combine. In addition, these firms have export linkages on six continents. Yet, since it does not qualify as a center of international finance, the city never has been or will be ranked among the world's most important cities by Global/World City theorists. Nevertheless, similar to other past and present Great Industrial Cities, such as Manchester, Essen, Detroit, Nagoya-Toyota, and Baoshan, Ulsan has become a vital cog in, and instrument of, global capitalism.

Great Industrial Cities are defined here as large, dense regional agglomerations of capital, labor, production, infrastructure, and knowledge, which provide substantial economies of scale and scope for firms in the same industrial sector (localization economies) and for firms in all industries (urbanization economies), and whose synergies incite an enlargement in the region's output, population, employment, and income. As production expands, scale coupled within innovative processes ultimately provokes substantial export production. What distinguishes a Great Industrial City from other urban conurbations is that its industrial sector or sectors become(s) highly influential internationally, even dominant. What makes them significant is the fact that their industrial production has fostered employment and income expansion not only in their city-regions, but in their nations on the whole.

Ulsan's rise to prominence in three industrial sectors suggests not only that is a Great Industrial City, but that it

\footnotetext{
*Address correspondence to this author at the Department of Sociology, East Carolina University, 405A Brewster, MS 567, Greenville, NC 27858, USA; Tel: 252-328-1933;

E-mails: drajjacobs@yahoo.com, jacobsa@ecu.edu
}

merits much greater attention than the scant coverage it has received in the English language scholarly literature. Chronicling its success also is necessary, as it demonstrates the decisive role that embedded factors have continued to play in urban and regional growth trajectories. As Jacobs [1] suggested in his Contextualized Model of Urban-Regional Development, Ulsan's growth path, similar to the world's other major city-regions, industrial or non-industrial, has been driven by global, supranational regional, national, and sub-national factors. Ulsan's development as a major manufacturing hub was facilitated by the policies of its national government. Its economy has remained heavily reliant on exports to other nations. Its growth context has been influenced by its nestedness within East Asia, including South Korea's historical relations with Japan and North Korea, and the linkages of Ulsan firms with Japanese manufacturers. Finally, Ulsan has benefited from its subnational context, particularly from its substantial and internationally influential agglomerations of motor vehicles, shipbuilding, and petrochemicals related manufacturing firms, as well as its proximity to other industrial cities in its region.

Overall, this study through its case study of Ulsan, seeks to not only introduce the concept of Great Industrial City, but also to: 1) remind scholars and practitioners about the continued importance of industrial cities for national economies and in global capitalism; 2) demonstrate how the world's city-regions have been decisively shaped by both international forces and embedded/nested factors; 3 ) enhance the English language reader's knowledge of South Korean urban areas; and 4) encourage scholars to more seriously consider the manufacturing sector when classifying world cities and delineating the global urban hierarchy, and thereby, expand the global-nested city debate beyond merely the analyzing of large financial centers. As a result, this article should prove of interest to urban and regional scholars and practitioners from multiple disciplines. 


\section{THEORIES ON THE WORLD'S IMPORTANT CITIES}

Numerous theories have been utilized by scholars to explain the growth trajectories of the world's major cities. Perhaps the most heated and interesting debate has been that between Global and Nested City theorists. Among the most frequently cited advocates of the first and more well-known perspective have been Friedmann [2], King [3], Sassen [4], Smith \& Timberlake [5], Knox \& Taylor [6], and Taylor [7]. These scholars essentially have argued that contemporary capitalism has effectively disembedded cities from their nation-states, and thereafter, allowed transnational corporations (TNCs) to seize control over urban space and re-organize for their own purposes. The ensuing economic restructuring has provoked the creation of a new international division of labor (NIDL), a stratified world system with an urban hierarchy led by a few dominant core cities, New York, London, and Tokyo.

While variations and debates certainly have existed within this thesis, World/Global Cities scholars generally have agreed that the primary determinants driving growth outcomes in city-regions were: 1) the number of interconnections a city-region has; 2) which city-region it was affiliated with; and 3) in which economic sectors the city-region had international network linkages. Those cityregions that have contained the greatest concentrations of financial and professional elites, and which have had the most interconnections with similar cities, have occupied to the top positions in the NIDL. From these 'great cities,' TNCs have reshaped other locations accordingly in the name of capital accumulation. Douglass [8] and Shin \& Timberlake [9] have been among the few scholars who have drawn upon this perspective to discuss South Korean cities.

The second paradigm, Nested City theory, has argued that while it was true that global forces have become increasingly more influential, cities have followed their own unique development paths, decisively influenced by their particular embedded contexts (e.g., their geographic location, national intergovernmental systems, economic mix, local institutions, and social-demographics) $[1,10,11]$. In the case of South Korea, Markusen \& Park [12, 13], Gallent [14], and Hassink [15] claimed that the State and not global flows has dictated urban industrial development in that nation. On the other hand, Hill \& Kim [16], Y.S. Lee [17, 18], Jo [19, 20], Bae \& Sellers [21], and Cho \& Hassink [22] suggested that multiple-tiers of nestedness have influenced growth trajectories in South Korean cities, including national government policies, metropolitan factors, and their location in Northeast Asia,. Examples of the latter offered included Japan's development of Seoul as its colonial financialadministrative core and of Daegu as a textiles center; technical assistance provided by Japanese steelmakers to POSCO in Pohang; and the foreign direct investment of Japanese electronics firms in Masan-Changwon.

Although utilizing different theoretical approaches, W.B. Kim [23], B.G. Park [24-26] and Y.S. Lee's [27] multi-scalar perspectives also suggested that contemporary urban economic growth in South Korea was now influenced by global, national, and local factors. Especially pertinent here was Park's review of Renault's takeover of the Busan-based Samsung Motors [24]. The conclusions of Multi-scalar and Nested city theorists were consistent with Jacobs' [1, 11],
Contextualized Model of Urban-Regional Development, which incorporates elements of several perspectives (including global, nested city, and agglomeration theory) in an attempt to explain the continued diversity of growth outcomes in the world's city-regions. Jacobs recommends that scholars consider the dynamic interplay among 11 contextual factors when examining the development patterns and status of the world's major cities:

1) Natural features - this factor accounts for the unique topographical features of an area, such as the existence of a deep harbor port, mineral deposits, and arable land;

2) Time-historical - this variable considers the age of the city-region/when it first developed and its nation's level of technological advancement;

3) Scale - this refers to the size of city-region's population and employment base;

4) Position in national urban hierarchy - this element has two sub-factors. First, it stresses that every nation has its own urban hierarchy, some are diverse and complex, others contain a primate city, etc. Second, a national capital region within a given nation will have different nested context than that country's noncapital regions;

5) Market-regional - this takes into account the region of the world in which a city is situated within, as well as its proximity to other urban areas within its nationstate, in nearby nations, and worldwide;

6) Economic-production - this factor considers a cityregion's industrial mix, the diversity of its economic base, the existence of industrial agglomerations or other business or knowledge clusters, as well as an area's physical infrastructure, and the degree and characteristics of its global economic integration (ex. the extent of its exports and imports);

7) Social-demographics - this variable reflects upon an area's racial-ethnic composition, its foreignborn/immigrant population, inter-group relations, the level of educational attainment, labor skill, and any socio-cultural aspects that may impact development;

8) Governmental structure - this element allows for national variations in governmental systems (e.g., unitary or federal), as well as in vertical and horizontal intergovernmental relations and their impact on a city-region;

9) National development context - this factor considers the development approach of a city-region's national government, such as liberal-regulatory $v s$ developmental;

10) Contemporary international events/forces - this factor accounts for the impacts of major global events, such as an economic crisis, war, currency fluctuations, and bilateral or multilateral trade disputes; and

11) Institutional reflexiveness - this incorporates into the model the policy capacity/innovative skill of national and sub-national governments, as well as firms located in the area. It also considers local variations in 
urban political economy, such as the existence of powerful growth machines or an anti-growth movement in the city-region $[1,11]$.

Among the most relevant factors from Jacobs' thesis which apply to Ulsan and which will be discussed shortly are: 1) its national development context and the Korean Developmental State ; 2) Contemporary International Events/Forces, particularly, the 1997 Asian Fiscal Crisis, trade disputes with the US and Canada, safety issues with Toyota cars, and the 2008 AIG-Lehman Shock; 3) its supranational regional context, specifically its historical and contemporary embeddedness in Northeast Asia; and 4) its sub-national context, including the city's substantial industrial agglomerations and inter-firm linkages within its sub-region and adjacent sub-regions.

In sum, drawing upon Jacobs' model, this article chronicles how Ulsan's rise to Great Industry City status was shaped by both global and embedded factors. This discussion begins after a presentation of some basic background information on Ulsan.

\section{BACKGROUND ON ULSAN}

Ulsan Metropolitan City is situated along the East Sea, within South Korea's newly defined Dongnam (Southeast) Economic Zone and the larger Gyeongsang Region. As shown in Fig. (1), the latter also includes the Daegyeong

\section{NORTH KOREA}

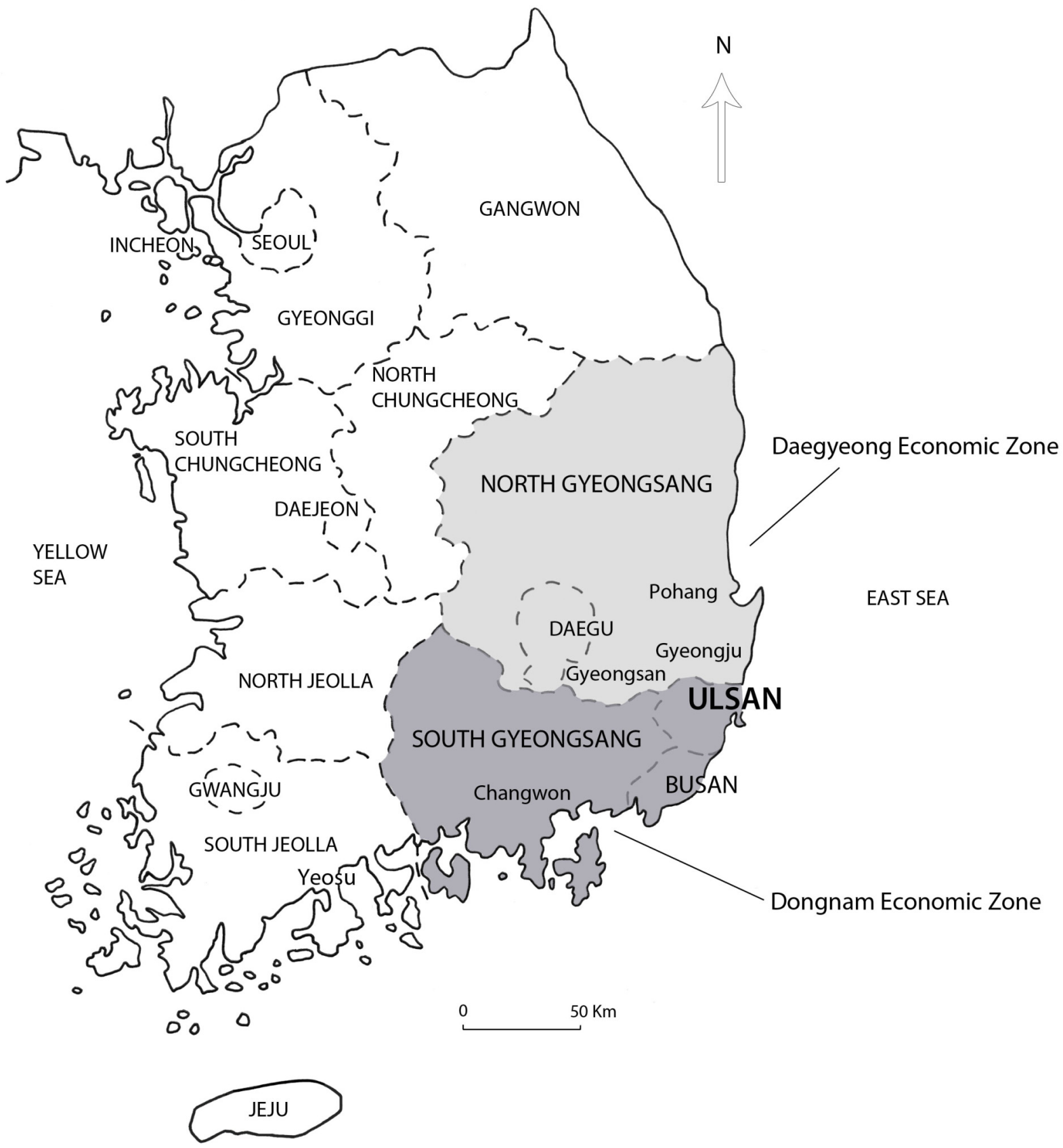

Fig. (1). Ulsan among South Korea's Provinces and Special Cities. 
Economic Zone. Originally settled as a fishing port, Ulsan's rise to industrial catalyst in its nation's economic development began on January 27, 1962, when in accordance with the First National Five-Year Economic Plan or NEP (1962-66), and Cabinet Order 403, the area was designated as a Special Industrial District (SID). A few months later, on June 1, under National Law 108, Ulsan Township was authorized as a city $(s i)$.

Over the next 15 years the Ulsan-si's population grew steadily, reaching 252,570 in 1975 , before doubling to 550,207 in 1985 [28]. Then, on 1 January 1995, after merging with Ulsan-gun (county) and adding roughly 150,000 new residents, the city's Census population rose to 967,429. Two years later, Ulsan surpassed one million inhabitants and was authorized under National Law 5243, as the country's sixth Gwangyeok-si or Metropolitan City. This designation placed it in South Korea's second highest municipal status category, behind only the National Capital of Seoul [29]. It also granted it functional independence from its province, South Gyeongsang. With 1,126,879 residents within an area of 1,056 sq. km (408 sq. miles) in 2008, Ulsan was its nation's seventh most populous city [30]. As shown in Table 1, the city's population had increased by 114,769 or $11.34 \%$ from 2000 .

Table 1. Change in Ulsan's Population, Total \& Manufacturing Employment, 2000-2008

\begin{tabular}{|c|c|c|c|}
\hline & $\mathbf{2 0 0 8}$ & $\begin{array}{c}\text { Change } \\
\mathbf{2 0 0 0 - 2 0 0 8}\end{array}$ & $\begin{array}{c}\text { \% Change } \\
\mathbf{2 0 0 0 - 2 0 0 8}\end{array}$ \\
\hline \hline Population $^{(1)}$ & $1,126,879$ & 114,769 & $11.34 \%$ \\
\hline Households $^{(1)}$ & 389,735 & 83,021 & $27.07 \%$ \\
\hline Total Employment $^{(1)}$ & 391,300 & 56,735 & $16.96 \%$ \\
\hline Manufacturing Employment & 146,481 & 17,670 & $13.72 \%$ \\
\hline
\end{tabular}

Sources: $[28,30]$.

Notes: ${ }^{(1)}$ Estimates obtained from the sources.

As for employment, as again illustrated in Table 1, based upon the national enterprise census and local estimates, in 2008 Ulsan establishments employed 391,000 workers.
Among these, 146,481 were engaged in manufacturing production. These figures represented increases of 56,735 or $16.96 \%$ in total and 17,670 or $13.72 \%$ in manufacturing employment from 2000. Whereas Ulsan's total employment ranked seventh most among South Korean cities, its industrial employment was second. Moreover, as presented in Table 2, Ulsan's post-2000 numeric increase in both manufacturing firms and industrial employment ranked first among the nation's seven major cities. This was significant considering manufacturing employment expanded in only two of the seven during this period (See Table 2).

As for specific sectors, Ulsan has the unique distinction of being the home to the world's: 1) largest automotive assembly complex and fifth biggest automaker, Hyundai Motor (HyMC); 2) largest dockyard and shipbuilder, Hyundai Heavy Industries (HyHI); 3) fourth largest producer of medium-sized container vessels, Hyundai Mipo Dockyard Co. (HyMD); and 4) second largest petrochemicals complex. It also hosted two of the globe's top eight refineries, operated by SK Energy and S-Oil, which combined to process more crude oil daily, 1.4 million barrels in 2010, than any other city on earth [31]. As a result, Ulsan ranked first among South Korean cities in employment in four manufacturing sectors: Motor Vehicles, Motor Vehicles Parts \& Trailers (MVM); 'Other' Transportation Equipment Manufacturing (OTEM), including shipbuilding; Chemicals \& Chemical Products; and Coke \& Refined Petroleum Products (See Table 3).

More specifically, in 2008 Ulsan's 410 Transportation Equipment Manufacturing (TEM) firms employed 91,819 workers, 49,378 in MVM, and 42,441 in OTEM (See Table 3). In all, TEM employment had increased by 19,518 of $27.00 \%$ from 2000 , and accounted for $62.68 \%$ of the city's total manufacturing employment in 2008. In addition, these sectors were supported by 440 firms employing 24,519 in related complementary manufacturing, for another $16.74 \%$ of the city's industrial workers. Although the Chemicals \& Chemical Products sector lost 5,110 jobs or $29.94 \%$ between 2000 and 2008, the city's 169 Petrochemicals and Nonmetallic Mineral firms still employed 17,889 workers in the latter year, including 11,955 in Chemicals.

Table 2. Manufacturing Employment Change: Metropolitan Cities \& Seoul, 2000-2008 ${ }^{(1,2)}$

\begin{tabular}{|c|c|c|c|c|c|}
\hline City & $\begin{array}{c}\text { Change in } \\
\text { Manufacturing } \\
\text { Firms } \\
\text { 2000-2008 }\end{array}$ & $\begin{array}{l}\text { Change in } \\
\text { Manufacturing } \\
\text { Employment } \\
2000-2008\end{array}$ & $\begin{array}{c}\text { \% Change in } \\
\text { Manufacturing } \\
\text { Firms } \\
\mathbf{2 0 0 0 - 2 0 0 8}\end{array}$ & $\begin{array}{l}\text { \% Change in } \\
\text { Manufacturing } \\
\text { Employment } \\
2000-2008\end{array}$ & $\begin{array}{c}\text { GDP } \\
\text { Per Capita } \\
2008\end{array}$ \\
\hline Seoul & $-1,480$ & $-49,684$ & $-22.21 \%$ & $-27.66 \%$ & $\$ 23,375$ \\
\hline Busan & -269 & $-23,826$ & $-6.51 \%$ & $-15.54 \%$ & $\$ 15,360$ \\
\hline Daegu & -124 & $-15,150$ & $-4.10 \%$ & $-13.93 \%$ & $\$ 12,975$ \\
\hline Incheon & -49 & $-22,623$ & $-1.08 \%$ & $-12.47 \%$ & $\$ 17,460$ \\
\hline Gwangju & 254 & 14,097 & $33.42 \%$ & $33.67 \%$ & $\$ 14,790$ \\
\hline Daejeon & 60 & -768 & $9.63 \%$ & $-2.34 \%$ & $\$ 15,075$ \\
\hline Ulsan & 325 & 17,670 & $35.79 \%$ & $13.72 \%$ & $\$ 46,370$ \\
\hline Korea & 7,311 & 143,358 & $14.29 \%$ & $6.20 \%$ & $\$ 20,210$ \\
\hline
\end{tabular}

Source: [28]

Notes ${ }^{(1)}$ Employment is by Place of Work.

${ }^{(2)} \mathrm{GDP}$ were rounded at the source and calculated using the July 1, 2008 exchange rate of 1,048.11 KRW to USD. 
Table 3. Ulsan's Manufacturing Employment by Sector, $20088^{(1)}$

\begin{tabular}{|c|c|c|c|c|}
\hline & $\begin{array}{c}2008 \\
\text { Establishments }\end{array}$ & $\begin{array}{c}2008 \\
\text { Manufacturing } \\
\text { Employment }\end{array}$ & $\begin{array}{c}\% \text { of } 2008 \\
\text { Manufacturing } \\
\text { Employment }\end{array}$ & $\begin{array}{c}\text { Employment } \\
\text { Change } \\
\text { 2000-2008 }\end{array}$ \\
\hline Transport Equipment Manufacturing ${ }^{(2)}$ & 410 & 91,819 & $62.68 \%$ & 19,518 \\
\hline --Motor Vehicles, Motor Vehicle Parts \& Trailers ${ }^{(2)}$ & 220 & 49,378 & $33.71 \%$ & 12,555 \\
\hline TEM-related Complementary Manufacturing & 440 & 24,519 & $16.74 \%$ & 5,134 \\
\hline Fabricated Metals & 180 & 7,926 & $5.41 \%$ & 1,212 \\
\hline Machinery \& Equipment & 164 & 7,823 & $5.34 \%$ & 4,278 \\
\hline Primary Metals & 62 & 6,094 & $4.16 \%$ & 513 \\
\hline Coke \& Refined Petroleum Products ${ }^{(2)}$ & 20 & 5,069 & $3.46 \%$ & 179 \\
\hline Non-metallic Mineral Products & 31 & 865 & $0.59 \%$ & -291 \\
\hline Other Manufacturing & 214 & 12,254 & $8.37 \%$ & $-1,760$ \\
\hline
\end{tabular}

Finally, all of Ulsan's manufacturing sectors were tremendously supported by the city's extensive port system, whose four harbors annually handled: 1) approximately $16 \%$ of South Korea's cargo tonnage; 2) more than $50 \%$ of the nation's crude oil imports; 3) almost 50\% of the country's automobile exports; and 4) more than $40 \%$ of South Korea's shipbuilding exports $[30,32]$. In concert with the city's industrial prowess, the port system has helped transform Ulsan into Asia's fourth largest manufacturing hub in terms of value of exports, and into a major catalyst in South Korea's economic growth over the past 35 years. Although not a focus of this article, the city's dense clustering of heavy and chemical factories unfortunately also have made the city infamous for its combative management-labor relations and its environmental pollution [33]. Nonetheless, similar to its positive achievements, these negative externalities were fostered by a combination of global and nested factors.

\section{INTERNATIONAL AND NESTED FACTORS DRI- VING ULSAN'S RISE TO 'GREAT' INDUSTRIAL CITY}

The next sections utilize some of the international, national, and sub-national factors suggested by Jacobs [1] in his Contextualized Model of Urban-Regional Development, to show how Ulsan's multi-layered nestedness has helped transform it into a Great Industrial City.

\section{A. National Development Context and the Korean Developmental State}

Drawing upon embedded autonomy theorists, such as Evans [34], Hill \& Kim [16], Jacobs [11] claimed that variations in national development context helped to explain the continued diversity in city-region growth trajectories. In light of its liberalization efforts since the 1990s, some scholars have questioned the continued effectiveness of the South Korea's state-led developmental approach [35-37]. Nonetheless, there is no disputing that the national government was the foremost catalyst driving Ulsan's rise to Great Industrial City status.

As mentioned, the origins of Ulsan as an industrial powerhouse began in 1962, when under the First NEP of military leader Chung-Hee Park (1961-79), the area was designated as a SID and the base for South Korea's oil and chemicals industries $[33,38]$. This decision was consistent with one of the primary goals of the plan: to end the nation's total reliance upon imported chemicals and fertilizers. To promote growth in its new target areas and sectors, the government encouraged firms to build facilities within SIDs, by offering them sizeable tax exemptions/credits, low interest loans, utility-rate subsidies, and tariff rebates on import goods utilized to create exports $[39,40]$. In addition, in 1962, the national government established the Korea Petroleum Energy Corporation (KPEC) in Ulsan, which two years later would open the nation's first oil refinery [41].

Unfortunately, while the plan's policies led to the establishment of a major petrochemicals complex in Ulsan in 1967, and fostered rapid growth in manufacturing employment, the leading petrochemical producers in the city were primarily foreign companies involved in joint ventures with local firms [42]. In response, government policies evolving from its Second NEP (1967-71) specifically targeted capital-intensive investment in chemicals, as well as in steel and machinery manufacturing [39, 43].

Next, in 1970, in an effort to relieve over-crowding and congestion in Seoul and Busan, the government again 
provided firms tax incentives to relocate factories to Ulsan and other designated SIDs [44]. These initiatives were accelerated under the Third NEP (1972-76), which came to be known as the Heavy Chemical Industrialization Plan (HCI Plan), which sought to turn South Korea into a world leader in petrochemicals manufacturing. According to Leipziger \& Petri [45], this strategy "was implemented through directed, subsidized credit, selective protection, regulations affecting industrial entry, and direct government involvement in industrial decision making." To lead this HCI drive, in 197475, the government designated four new growth poles: Yeocheon (now Yeosu, for petrochemicals); Changwon (machinery, especially for defense industries); Pohang (iron and steel); and Ulsan (chemicals, automobiles and shipbuilding). Thereafter, in 1982, Onsan (petrochemicals), at the time just outside of the Ulsan city limits in Ulsan-gun, was established $[12,44]$.

As a direct result, "by 1973 an independent Korean chemical complex [had] emerged in Ulsan... [and with it], the nation's dependence on imports of synthetic fiber for its textiles industry nearly disappeared" [42]. Moreover, the number of petrochemical plants in the city had increased from just two in 1963 to 51 in 1978 [38, 44]. Finally, the HCI Plan laid the foundation for the expansion of KPEC's oil operations in Ulsan. Purchased by SK Energy in 1980, this complex would ultimately become the world's second largest single refinery and the centerpiece of a network which currently extends into 14 countries on five continents. Through SK Gas, which established its first liquefied gas plant in Ulsan in 1985, SK became South Korea's largest gas station operator; the firm currently possesses a $34 \%$ domestic market share while operating 3,670 stations, nationwide [41].

As for other prominent industries in Ulsan, in 1962-63, in conjunction with the First NEP import-substitution and export-oriented goals, the government enacted the Automobile Industry Promotion Law and the Automobile Protection Act. These measures eventually led to Hyundai opening a vehicle manufacturing plant in Ulsan in 1968, where it assembled a small lot of complete knock down (CKD) cars for Ford Motor Company [17, 46, 47]. Shortly thereafter, Hyundai's chances for success changed dramatically positive, when the early 1970s, the national government set out to build its own MVM industry [39, 42, 44, 48].

In accordance with the HCI Plan, in 1975 the South Korean Government passed the Enterprises Affiliation Promotion Law, which encouraged and subsidized the clustering of auto parts and components makers. One of the prime focus areas for an auto cluster was the newly designed growth pole of Ulsan. Next, under the Fourth NEP (197781 ), the government targeted the automotive industry as a strategic industry for export promotion, and extended special subsidies to suppliers and subcontractors affiliated with domestic manufacturers [49]. As a result, by December 1975, when the first Pony rolled off the HyMC's Ulsan assembly line, South Korea was producing its own cars. Within a year, HyMC exported the nation's first car from Ulsan. In addition, by the late-1970s, $90 \%$ of the parts in the typical Korean car were domestically manufactured [42].

During the 1980s, buoyed by HyMC's Excel subcompact, export production expanded significantly in Ulsan.
These efforts were greatly enhanced by the national government's passage of the Automobile Industry Rationalization Policy in 1981, which protected the domestic auto industry by limiting passenger car manufacturing to two companies: HyMC and GM-Daewoo's Saehan Motors [46]. Over the next 15 years, this and other national policies, such as currency interventions, preferential tax and credit incentives, and periodic crackdowns on labor/the relaxation of labor laws, combined with other factors to be discussed, transformed HyMC into a major international automaker [35].

In 1996, annual vehicle production at the firm's Ulsan complex had exceeded one million vehicles. Then, in 1998, in the midst of the 1997 Asian fiscal crisis, which left the auto industry, among others, in financial peril, HyMC absorbed the nation's second largest automaker, Kia Motors. By the end of the 2000s, the Hyundai-Kia brands had rebounded from the crisis and commanded a roughly $70 \%$ share of the domestic market. At that time, domestic vehicles production stood at 2.74 million, export sales had exceeded one million, and HyMC's total vehicle production had soared to 4.65 million [50-52]. Meanwhile, the firm's Ulsan operations had been transformed into the world's largest assembly complex, a 5.05 square kilometers site (54.35 million square feet) containing five independent plants, with a vehicle capacity of 1.7 million vehicles and employing 34,000 people. By 2010, as a direct result of its national developmental approach, the former CKD assembler based in Ulsan had become the world's fifth largest automobile producer [52].

National plans and policies introduced during the 1960s and 1970s also were vital to Ulsan's rise to top of the global shipbuilding industry. In order to create a private domestic shipbuilding industry, the government introduced the 1962 Shipbuilding Industry Encouragement Act, again offering direct subsidies (up to $30 \%$ of the production costs to build local shipyards), "duty-free imports on parts and materials [and] loans to companies replacing old ships" [43]. Under the Second and Third NEP, two more Shipbuilding Promotion Acts were enacted (in 1967 and 1973), as well as the Machinery Promotion Act (1969). Together, supported by the Korea's Export-Import Bank, this legislation extended subsidies and favorable financing to domestic shipbuilders and parts suppliers.

Similar to HyMC, HyHI's success also was greatly aided by the national political connections of its founding family and its business conglomerate, the Hyundai Jaebeol or chaebol, extending as high up as President Park. For example, for much of the past 50 years, a disproportionate proportion of high-ranking national officials have hailed from South Gyeongsang Province. This included Mong-Jun Jeong, then president of HyHI and son of Hyundai's founder Ju-Yeong Jeong, who was elected to the national assembly in 1988 representing Ulsan [24, 53]. These linkages netted HyHI countless government contracts to construct ships, national infrastructure, and industrial facilities projects. It was within this context that HyHI broke ground on its massive shipbuilding operations along Ulsan's Mipo Bay in 1972, and was granted a special national policy exception allowing it to secure technical assistance from foreign shipbuilders. As a result, by the mid-1980s, the firm had 
become the world's largest shipbuilder, employing as many as 30,000 workers at its Ulsan dockyard [43, 46, 48]. By 2010 , HyHI held a $15 \%$ share of the world shipbuilding market and had offices and subsidiaries in 22 countries on five continents. Moreover, its Ulsan-based affiliate, HMD, had become among the top four producers of mid-sized container vessels [54].

In sum, as Dicken [55] wrote in reference to the auto industry, but which also applies to the petrochemicals and shipbuilding industries: "The US, Japanese, and European automobile companies exert such market dominance that there have been virtually no new entrants to the industry during the past 30 years. The major exception is South Korea, which emerged in a space of just a few years as a significant international force, directly as a result of state involvement." While global liberalism may have loosened its grip over its economy, the South Korean Developmental State led Ulsan's rise to Great Industrial City status. This involvement continued in 2010, when national government Korean State provided 27 billion Korean Won (KRW or \$25.76 million) to construct the Ulsan Free Trade Zone, on a 1.30 square kilometers site (13.97 million square feet) in the city's Ulju-gu's Sin-Il General Industrial Complex [32].

\section{B. International Forces Impacting Ulsan's Growth Path}

Influenced by Dicken and others, Jacobs claimed that the more integrated into the world economy a city's firms were, the greater the frequency and magnitude it was impacted by international events. As a result of their export orientation of its major manufacturing firms, Ulsan's fate certainly has been tightly linked to the global economy. Examples of international factors which have significantly affected the city's growth path have included the: 1) 1997 Asian Fiscal Crisis; 2) friction caused by South Korean trade surpluses with the US and Canada; 3) Toyota's 2010 safety issues with its US vehicles; and 4) low KRW relative to the Japanese Yen (JPY) of the late-2000s, especially following the AIGLehman Shock of September 15-16, 2008.

Among the many impacts of the 1997 Asian Fiscal Crisis was the dramatic depreciation of the Korean Won (KRW), which forced the South Korean Government to turn to the IMF for aid, and left the nation's largest jaebeol in fiscal distress $[53,55]$. In response, the government promulgated its Big Deal Program, which set out to rationalize the nation's energy, electronics, and TEM sectors by encouraging the restructuring of, and business swaps among, the jaebeol [40]. This was a mixed blessing for Ulsan's Hyundai Group. On the one hand, it was placed instructed by the government to become more focused on its heavy industries and shipbuilding operations by divesting itself of some of its assets. On the other hand, in 1998, HyMC was allowed to take over the failing Kia Motors. This gave the firm the economies of scale and financial stability needed to invest heavily vehicle quality. This accelerated its move away from "being merely a low-price regional producer of cars primarily for Asian markets," to a company whose Ulsan exports comprised a significant and rising share of North American and European auto sales [55].

Finally, the Asian Fiscal Crisis led to the election of a more democratic national government and later, the rapid decentralization of political power in South Korea. While both would prove advantageous to the society in the longrun, the new government's attempts at economic liberalization and labor reform, most dictated by the terms of the IMF bailout, ultimately provoked a geographic shift in HyMC's production. As a result, while Ulsan's plants remained the core of HyMC's worldwide manufacturing activities, by 2009 it produced only about $30 \%$ of its vehicles in the city, as compared with twice that in 2000 [50]. In 2011, Hyundai-Kia vehicles were built in 22 countries on five continents. This included 16 group-owned final assembly complexes situated in eight nations, and 24 CKD operations in 17 countries. Among Hyundai-Kia plants, 10 plants were overseas and the rest located in six separate South Korean municipalities. The newest facility was HyMC's St. Petersburg, Russia plant, which opened in September 2010. The group, which was expected to open its $11^{\text {th }}$ overseas factory in Sao Paulo Brazil in 2012, now has subsidiaries and sales affiliates in nearly 200 countries [51, $52,56]$.

As for trade issues, during the 1980 s, relations with North American were frayed due to South Korea's large trade surpluses with the US and Canada, particularly related to imported automobiles. According to Bello \& Rosenfeld [35], nearly $40 \%$ of South Korea's " $\$ 6.5$ billion trade surplus with US in 1988 was... accounted for by its exports of automobiles and auto parts," Leading the charge was HyMC and its best-selling Ulsan-built subcompact, the Excel. At that time, HyMC also threatened with of import quotas from Canada [47].

Within this context, and after receiving $\$ 131$ million in incentives from the Canadian and Quebec governments, HyMC constructed a $\$ 387$ million plant just 45 minutes east of Montreal, in Bromont, QC. With an annual capacity of 100,000 vehicles, it began producing Sonatas there in April 1989 , under the assumption that the new factory "would enable it to get into the North American market on a far larger scale than was possible by shipping [cars] from Ulsan" [46]. Despite these major investments, constant quality problems doomed Bromont production from the start, and the plant was shuttered in 1993.

Over the next decade, this lesson taught HyMC that any successful entry into North American required major improvements to quality. As mentioned, aided by its merger with $\mathrm{Kia}$, this was accomplished during the 2000s, when North America sales from Ulsan roughly doubled to 450,000 vehicles. Meanwhile, a significantly expanding trade surplus with the US served to reignite friction between the two countries. In response, HyMC decided to once again produce cars in North America, this time constructing a manufacturing complex in Montgomery, Alabama in 2005, with an annual capacity of 300,000 vehicles; in 2010, the plant produced 300,500 vehicles with a domestic content of $80 \%$ [50,52]. Then, in November 2009, it began production at a Kia factory in West Point, Georgia, just 90 miles northeast of Montgomery, equally capable of manufacturing 300,000 vehicles annually [51]. It also was considering reopening its Bromont plant in 2011. In contrast, the group cut back on its vehicle exports from Ulsan, where production was basically flat during the 2000s.

HyMC's new U.S factories also proved fortuitous in the light of a third international event, a barrage of damaging 
news stories in early 2010 and the subsequent US Congressional hearings alleging safety issues with Toyota Motor's most popular vehicle models (i.e., sudden acceleration). As a direct result, US vehicle sales of the Hyundai-Kia Group rose by $21.7 \%$ to 894,496 in 2010 as compared with 2009 [57]. While very little of this increase was from exports, Ulsan-based auto suppliers benefited tremendously from a related rise in demand for parts installed in the firm's increasingly popular American-made models; sales of the Hyundai Sonata sedan rose by $63.8 \%$ from 2009 to 196,623 [57]. Perhaps unfortunate for the city however, was HyMC's decision to shift some of its Elantra subcompact model production from Ulsan to Alabama, beginning in November 2010.

A final dramatic global factor affecting Ulsan employment was the depreciation of the KRW during the late-2000s, relative to the currency of its major export competitors the JPY. This trend began in January 2008 and accelerated rapidly following the September 15-16, 2008 collapse of two giant US financial services firms, AIG and Lehman Brothers. Fig. (2) illustrates how relatively 'low' against the JPY the KRW has become, by comparing annual exchange rates between 1997 and 2010. Since the KRW essentially has an extra digit below cents (i.e., $1000 \mathrm{KRW}=$ $100 \mathrm{JPY}$ ), to normalize the two rates to 1.000 , the KRW rate per $10 \mathrm{JPY}$ was used. In the chart, a reading below 1.000 signified that the KRW's value was 'low' relative to the JPY, favoring Ulsan exporters. Conversely, a ratio of greater than above 1.000 meant that the KRW was 'high' $v s$ the JPY, favoring Japanese exporters.

As shown in Fig. (2), after fluctuating around par or 1.000 between December 31, 2001 and December 31, 2004, the KRW appreciated against the JPY. It then returned to its 2004 level just before the AIG-Lehman Shock, after which, in the weeks to follow, international investors aggressively sold off KRW and USD and bought JPY. This led to the concurrent rapid rise in the JPY against the USD and an equally dramatic fall in the KRW. These combined events resulted in the KRW being even cheaper against the JPY (.719) on October 31, 2010, than it was at the height of the 1997 Asian Fiscal crisis (see December 31, 1997, when it was at .775).

This situation created a significant pricing advantage for Ulsan exporters over their Japanese competitors, which was enhanced by two factors: 1) in the late-2000s, Ulsan manufacturers were much less dependent on Japanese imports as compared in 1997 ; 2) during the Asian Fiscal Crisis, the JPY also dramatically depreciated against the USD, resulting in equivalent KRW to JPY rates against the USD rather than a 'low' KRW (Again, see Fig. 2). One outcome of this was, despite HyMC's new US plants, Ulsan city manufacturing employment expanded by $17.11 \%$ or 6,201 jobs between 2007 and 2008. Approximately 94\% of this was in MVM and OTEM, each of which added more than 2,200 workers. A similar expansion was expected for 2009-10 based upon an even lower KRW [58].

In sum, the Asian Fiscal Crisis, trade friction with North America, the Toyota vehicle recalls of 2010, and the AIGLehman Shock/'low' KRW vs the JPY, all demonstrate how Ulsan's growth cycles, similar to that of other Great Industrial Cities, have been forcefully shaped by international political-economic forces. By the same token, with firm linkages on six continents, South Korea's industrial heartland has become an important node in global capitalism.

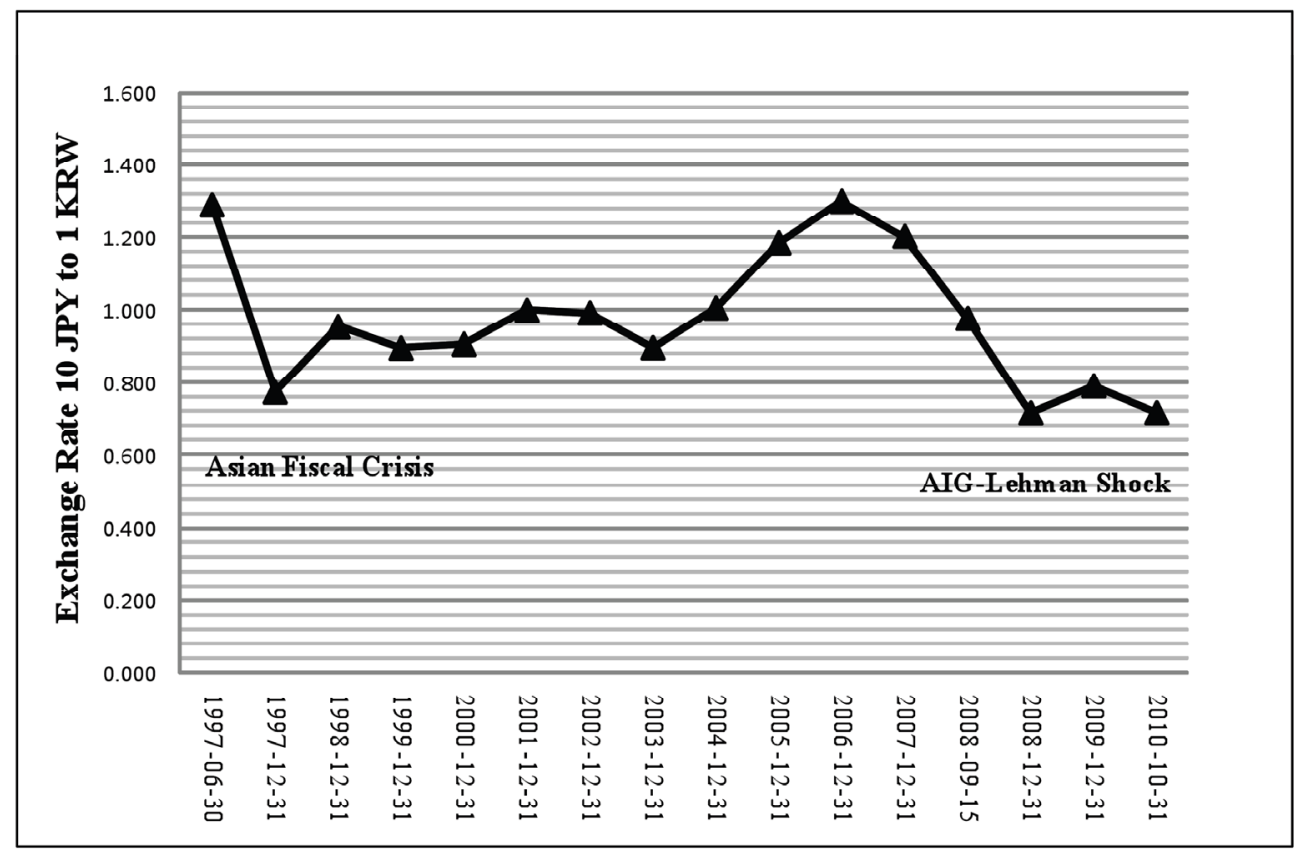

Notes. Since the KRW is denominated in 1,000 to the USD as compared with 100 Yen, the figures above were adjusted or normalized by utilizing the KRW to $10 \mathrm{JPY}$ rate. In other words, if the JPY to KRW was .1000, it was represented above as 1.000. Therefore, a figure of $<1.0$ meant that the KRW was 'low' relative to the JPY, while $>1.0$ meant the KRW was 'high'.

Fig. (2). KRW to JPY Normalized Exchange Rates, 1997-2010. 


\section{Ulsan's Supranational Embeddedness in Northeast Asia}

Drawing especially upon Hill \& Fujita [10], Jacobs [1] contended that the region of the world an urban region was situated within uniquely influenced its growth path. South Korea is located in Northeast Asia, on a peninsula just 120 miles across the Korean Strait from Japan. To its north is North Korea, itself bordered by China, to its northwest, and Russia, to its northeast. Historically, this geographical embeddedness has placed the nation, as well as its cities and firms, in the middle of some precarious and advantageous political-economic circumstances. For example, for most of the Yi Dynasty (1392-1910), Korea was on friendly terms with Japan and was a protectorate of China. Conversely, from 1910 to 1945, Korea was a colony of Imperial Japan. This marked a period of severe repression and exploitation of its people that the two nations have yet to overcome.

In addition to political and territorial ramifications, Japanese colonization also had a lasting effect on South Korea's economic and industrial development. Initially, Japan dismantled Korea's feudal class divisions and its prohibitions on private property ownership established during the 1,000 year Yi dynasty. Moreover, it constructed the energy, transportation, financial, and commercial infrastructure necessary to modernize and industrialize the country. Nevertheless, such endeavors were not part of a strategy to make Korea self-sufficient, but rather to support Japan's empire building. This was especially apparent following Japan's annexation of Manchuria in the 1931, when Korea became a frontline supply base for its military advances in China. It also was evident with regards to Japanese investments in Korean education, which although high, were not intended to build a thriving middle class, but rather to assimilate Koreans at the bottom of Japanese society. Finally, following a bloody uprising in 1919, the Japanese purposefully cultivated a Korean capitalist class in order to quiet the masses. This bourgeois class would later resurface as the political, economic, and social elites of postcolonial South Korea [42, 59-62].

Following its defeat in World War II (WW II), Japan withdrew from Korea in 1945, resulting in its partitioning into the present-day North and South Koreas. Only five years later, the nation was thrust into the middle of an ideologicalbased war (1950-53) between capitalism (aided by America) and socialism (supported by Chinese and the USSR). When peace was restored, the civil economy of South Korea's economy became concentrated in textiles and light manufacturing, led by a small number of large companies run by members of the aforementioned Japanese-fostered colonial elite, operating out of formerly Japanese plants [60].

The influence of Japan continued after General Park seized power via a military coup in May 1961. Although fervently nationalistic, the new President was inspired most by the strategies of Japan's late-19 ${ }^{\text {th }}$ Century Meiji Government, especially its 'rich nation, strong army' doctrine, which called for the cultivation of a loyal business class. As a result, members of the bourgeoisie were jailed and their fortunes commandeered, only to be released and their wealth returned, if they committed to invest in the best interest of economic nationalism $[60,62]$. This set the stage for the formation of the South Korean jaebeol, such as
Hyundai, whose size and diversification mirrored that of Japan's pre-war zaibatsu business conglomerates. Park's NEP and ambitious export-oriented strategy, which rapidly pushed South Korea's industrial mix toward HCI, also were inspired by Japan's pre- and post-WW II success. Park picked Ulsan to play a key role in this drive because of its deep harbor, vacant land, and most importantly, similar to the other districts developed in the nation's southeast, its location, because it was as far away as possible on the peninsula from North Korea.

Park's 'Look East' policy also re-established linkages with Japanese companies, a decision which proved particularly beneficial for Ulsan's post-1960s economic growth [11, 42, 48, 63]. For example, the Ulsan-based HyHI and HyMC owe much of their success to the tutelage of the Japanese firms, particularly, Kawasaki Heavy Industries (KHI) and Mitsubishi Motors (MMC), respectively. As part of this technical assistance, KHI invited 200 Korean engineers and technicians to Japan for training, provided HyHI with proven designs for ships, and subcontracted with the firm to build its first two tankers [48]. As for the HyMC, since 1973, it has received financial and technical support and has been involved in several joint ventures with MMC. HyMC's first Pony models were built with MMC engines and transmissions. In 1982, MMC purchased a $10 \%$ stake in HyMC, with the latter agreeing to produce about 30,000 cars annually using the Mitsubishi Precis nameplate. Later, this partnership made it possible for HyMC to begin exports of its Excels to Canada in 1984, then to the US in 1986, and to the opening of HyMC's Bromont, Quebec plant in 1989 [35, $49,64]$.

Based upon a MMC design, between 1992 and 1998 the two firms jointly made the Hyundai Grandeur, "the best known, domestically manufactured, luxury car in South Korea;" the car essentially was a Mitsubishi Debonair produced in Ulsan with a Hyundai badge [63]. After 1998, the Grandeur became solely a Hyundai production, but was succeeded by the Ulsan-built Hyundai Equus, briefly sold in Japan as the Mitsubishi Dignity limousine, and then by the Hyundai Dynasty/Mitsubishi Proudia [52]. Modeled originally on its Gallant platform, between 1988 and $1998 \mathrm{MMC}$ also supplied engineering and core components (imported or licensed) to the Hyundai Sonata, at the time, built in Ulsan. MMC's equity holdings in the firm remained around $15 \%$ during this period, before declining through 2003, when it sold off its remaining HyMC shares. Until September 2009, when bought out by their partner Chrysler, the two firms still jointly developed engines for their Gallant and Sonata models, among others, through their Global Engine Manufacturing Alliance [52, 64].

Finally, technology transfer and guidance from Japanese steel, machinery, and auto and shipbuilding parts suppliers, also have greatly contributed to employment growth in related plants in Ulsan $[48,63]$. POSCO, the world's third largest steelmaker in 2010, and a main supplier to HyHI and HyMC for roughly 40 years, was the most prominent example of this. The firm initially was a turnkey operation of Nippon Steel, constructed primarily with parts produced, and with staff trained, in Japan. In sum, Ulsan's historical and more recent linkages with Japan demonstrate how its post- 
war growth trajectory has been deeply embedded within Northeast Asia.

\section{Ulsan's Sub-national Agglomerations and Inter-local Linkages to Growth}

Melding Alfred Marshall [65] and Jane Jacobs' [66] conclusions regarding industrial districts with Isard [67], and Scott \& Storper's [68] claims related to regional agglomerations, Jacobs $[1,22]$ maintained that collaboration, among firms and among municipalities within the same geographic region, can have a positive effect on a city's growth trajectory [69]. As a Great Industrial City, Ulsan is a prime example of an area whose industrial firms have greatly benefitted not only from national government policies and international linkages, but from its nestedness within two regional industrial agglomerations: the Dongnam Economic Zone and the larger Gyeongsang Region. The latter encompassed Dongnam, and the newly designated national economic bloc to its north, the Daegyeong Economic Zone (Again, see Fig. 1).

As previously shown in Tables $\mathbf{1}$ and $\mathbf{3}$, in 2008, Ulsan was a Metropolitan City of 1.13 million people and 391,000 in total employment. Whereas, these both ranked seventh nationally among cities, its manufacturing employment of 146,481 , stood second. The latter included a clustering of 410 TEM firms employing 91,819, supported by another 440 firms with 24,519 workers in the complementary industries of Fabricated Metals, Machinery \& Equipment, Primary Metals, and Plastics \& Rubber Products manufacturing [28, 32]. All combined, these firms, in concert with those in Petrochemicals \& Non-metallic Minerals and the city's extensive port facilities, have formed "a horizontally integrated industrial system" in Ulsan, which has been a significant catalyst driving South Korea's economic growth over the past 35 years.

Yet, while Ulsan itself qualifies as a regional industrial agglomeration, its firms also have been dependent upon linkages with businesses dispersed among municipalities within its larger economic zone and region. As of 2008, the Dongnam Economic Zone, which encompassed the Metropolitan Cities of Ulsan and Busan, plus the localities in South Gyeongsang Province, had an estimated 7.93 million residents, 2.54 million in total employment, and 11,346 manufacturing establishments employing 590,643 workers (See Table 4 and Fig. 1). Among the latter were 1,921 firms employing 212,444 in TEM. This included 918 establishments and 85,483 workers in MVM, and 1,003 and 126,961, respectively, in OTEM. These firms were complemented by 5,464 Metals and Machinery companies with 209,826 in employment.

The economic zone's largest city was Busan, with 3.57 million residents and 1.15 million in employment, both second most nationally. It also contained 129,500 manufacturing jobs, including a Renault Samsung auto factory. Following Busan and Ulsan was Changwon, a city in South Gyeongsang Province which following its July 1, 2010 merger with Masan and Jinhae had a population of 1.08 million. The new unified city was a core for machinery and fabricated metals production, and home to GM-Daewoo and Ssangyong Motors engine plants [28, 32, 70].

Finally, Ulsan's TEM cluster also has been aided by complementary manufacturing firms within the Daegyeong Economic Zone, which encompassed Daegu Metropolitan City and the municipalities in North Gyeongsang Province. In total, Daegyeong had an estimated 5.17 million in population and approximately 1.52 million in employment in 2008, of which 306,285 were in manufacturing (Again, see Table 4). Especially relevant for Ulsan factories were the clusters of: automotive parts plants in Gyeongju city; fabricated metals and parts suppliers in Daegu; machinery makers in Gyeongnan city; and most of all, the previously mentioned POSCO complex in Pohang, a city of more than 500,000 , located $70 \mathrm{~km}$ (44 miles) north of Ulsan. For nearly 40 years a significant share of POSCO's Pohang output has been sent to HyMC and HyHI's Ulsan plants. So intertwined have been these firms that in July 2010, HyHI, HyMD and POSCO deepened their long-held cross-shareholdings ties. Moreover, just two months later, POSCO opened a large new mill in Alabama to serve HyMC and its suppliers in the emerging US Southern Automotive Corridor.

As a result its numerous agglomeration/production synergies, Ulsan's total value of exports of $\$ 78.8$ billion in 2008, ranked first among South Korea's seven special cities; its figure was equivalent to $18.7 \%$ of the nation's total $[71$,

Table 4. 2008 Population and Employment for Ulsan and its Surrounding Area ${ }^{(1,2)}$

\begin{tabular}{|c|c|c|c|c|}
\hline & Population & Total Employment & Manufacturing Employment & Manufacturing Firms \\
\hline DONGNAM ECONOMIC ZONE & $7,926,474$ & $2,541,340$ & 590,643 & 11,346 \\
\hline -Ulsan Metropolitan City & $1,126,879$ & 391,300 & 146,481 & 1,233 \\
\hline -Busan Metropolitan City ${ }^{(3)}$ & $3,574,340$ & $1,150,000$ & 129,500 & 3,865 \\
\hline -South Gyeongsang Province & $3,225,255$ & $1,000,000$ & 314,662 & 6,284 \\
\hline ---Changwon city ${ }^{(4)}$ & $1,080,441$ & NA & NA & NA \\
\hline DAEGYEONG ECONOMIC ZONE & $5,167,449$ & $1,520,000$ & 306,285 & 6,874 \\
\hline -North Gyeongsang Province & $2,654,845$ & 800,000 & 212,686 & 3,973 \\
\hline -Daegu Metropolitan City & $2,512,604$ & 720,000 & 93,599 & 2,901 \\
\hline
\end{tabular}

Sources and Notes:

(1) Population and Total Employment estimates from city and provincial sources [30, 70, 76, 77].

${ }^{(2)}$ Employment is by place of work. Manufacturing Employment obtained from KOSIS [28] National Data.

${ }^{(3)}$ Busan population for 2009 .

${ }^{(4)}$ Population is for July 1, 2010, and is the total of the merged cities of Changwon, Masan and Jinhae. 
72]. In addition, as presented in Table 2, at 48.6 million KRW (\$46,370 US), it had the highest GDP per capita among these cities, a figure that was more than twice the national average [28, 73]. Next, Ulsan's agglomeration economy has allowed it to maintain a strong employment and industrial base, despite economic downturns and other dramatic world events during the 2000s.

As previously shown in Tables 1-3, between 2000 and 2008 , the city added 56,735 in total employment, along with 325 industrial firms and 17,670 in manufacturing employment, both again tops among the seven special cities. This was noteworthy considering that during this period industrial employment contracted in five of the seven, with four suffering net losses in their manufacturing firms. Finally, industrial expansion has fueled both population and income growth in Ulsan. The city's population rose by 114,769 during the 2000s, and its per capita income expanded to 15.3 million KRW (\$14.598) in 2008. The latter ranked second highest among special cities, and trailed only the national capital, Seoul, by a mere $\$ 191[28,73]$.

Overall, along with the other influences previously chronicled, Ulsan's nestedness within the Dongnam Economic Zone and the Gyeongsang Region has been a decisive factor shaping its transformation into a world-connected, Great Industrial City, Asia's fourth largest manufacturing hub in terms of value of exports, with firm linkages on six continents. The city government has established several new initiatives to help maintain this status, specifically aimed at building upon and strengthening its international competitiveness in MVM. This has included: the construction of seven new industrial/research \& development parks as part of its Auto Valley Project; and a September 2010 agreement with Samsung SDI and others establishing a 'Battery Industry Promotion Council,' aimed at nurturing the development of a battery industry in Ulsan [32]. A final industrial park focusing upon advanced chemicals production was schedule to open sometime in 2011. This park hopes to complement the city's petrochemical industries, which in 2009 already ranked fifth worldwide in total volume of ethylene produced, as well as manufactured two-thirds of the nation's export volume in this sector $[32,74]$.

Unfortunately, Ulsan's dense clustering of heavy and chemical industries also has resulted in it becoming its nation's most polluted city. For example, before its rehabilitation in the 1990s, the level of contaminants in its Taehwa River prompted national observers to dub it: 'the River of Death' [75]. In addition, the growing international reputations of its firms, particularly HyMC and HyHI, frequently aided by the government, have fostered highly combative management-labor relations, and have led to South Korean annual working hours ranking among the highest for OECD countries. Nonetheless, similar to its positive achievements, these negative outcomes were facilitated by global forces and the city's supranational, national, and sub-national historical and political-economic nestedness.

\section{CONCLUSION: LESSONS FOR/FROM 'GREAT" INDUSTRIAL CITIES}

This article began by claiming that Ulsan, as a result of it being the home to the world's largest shipyard and shipbuilder, its biggest auto production complex, its fifth largest auto producer, and one of its largest petrochemical complexes, qualified as a Great Industrial City (i.e., one of the world's major and influential industrial agglomerations). Second, drawing upon Jacobs' [1] Contextualized Model of Urban-Regional Development, it showed how Ulsan's path toward Great Industrial City status was decisively shaped by both global forces and embedded factors. While the weight of each scale has fluctuated over time, both have been vitally important.

In the process, it sought to not only to introduce the concept of Great Industrial City, but also to: 1) remind scholars and practitioners about the continued importance of industrial cities for national economies and in global capitalism; 2) demonstrate how the world's city-regions have been decisively shaped by both international forces and embedded/nested factors; 3) enhance the English language reader's knowledge of South Korean urban areas; 4) encourage scholars to more seriously consider the manufacturing sector when classifying world cities and delineating the global urban hierarchy, and thereby, expand the global-nested city debate beyond merely the analyzing of large financial centers.

As suggested by Jacobs' [1] model and others, Ulsan, similar to all modern Great Industrial Cities, such as Toyota City, Stuttgart, Detroit, Sheffield, and Baoshan, has been significantly supported by the policies of its national government. In the case of Ulsan, the interventional Korean Developmental State, with its NEP, industrial district location decisions, and strategic targeting of specific manufacturing sectors, among other policies, was the foremost catalyst steering its growth path. However, like the others cities previously mentioned, international forces also were highly influential. For Ulsan, the Asian Fiscal Crisis of 1997, trade friction between South Korea and North America, the AIG-Lehman Shock of 2008, and the Toyota safety recalls of 2010 were examples of such factors. Moreover, its prosperity was heavily reliant upon the export of manufactured goods to other nations within an ever expanding global economy.

Next, Ulsan's growth trajectory was dramatically shaped by its location within East Asia, where South Korea's historical relations with Japan and North Korea, and connections between Ulsan local industries and Japanese firms, among other factors, have been crucial. The same could be said for Great Industrial Cities situated in North America, Western Europe, Southeast Asia, etc. Finally, similar to that of Detroit, Toyota City, and the others, Ulsan has benefited from its sub-national context, particularly its dense agglomeration of MVM, shipbuilders, petrochemical producers, and related supplier firms, its extensive port system, and linkages with complementary establishments located in other municipalities within the Dongnam Economic Zone and the larger Gyeongsang Region.

In sum, consistent with Jacobs' model, global, supranational regional, national, and sub-national contextual factors have combined to transform Ulsan from a fishing port into one of the world's Great Industrial Cities, Asia's fourth largest in terms of value of exports, with firm linkages on six continents. Most importantly, its industrial growth has driven employment and income growth not only in the city, but also in its region and nation on the whole. As such, Ulsan's rise demonstrates the continued importance of 
studying industrial cities. It hopefully also encourages other English-language scholars to more closely examine South Korean city-regions.

\section{ACKNOWLEDGEMENT}

The author would like to thank Shin S. Lee, Paul Waley, and Jennifer B. Jacobs for their comments on the article, as well as Sarah Searcy, Young-Hun Kim, and Hyun-Woo Kim for their help with the article's maps and data collection.

\section{REFERENCES}

[1] Jacobs AJ. Embedded contrasts in race, municipal fragmentation, and planning: divergent outcomes in the Detroit and Greater Toronto-Hamilton regions 1990-2000. J Urban Aff 2009; 31: 14773. [Particular see pp. 167-68].

[2] Friedmann J. The world city hypothesis. Dev Change 1986; 17: 6983.

[3] King A. Global cities: post-imperialism and the internationalization of London. New York: Routledge 1990.

[4] Sassen S. The global city. Princeton, NJ: Princeton University Press 1991.

[5] Smith D, Timberlake M. Conceptualizing and mapping the structure of the world system's city system. Urban Stud 1995; 32: 287-302.

[6] Knox P, Taylor, P. Eds. World cities in a world system. New York: Cambridge University Press 1995.

[7] Taylor P. World city network: a global urban analysis. New York: Routledge 2004

[8] Douglas M. Social, political and spatial dimensions of Korea's industrial transformation. J Contemp Asia 1993; 23: 149-72.

[9] Shin KH, Timberlake M. World cities in Asia: cliques, centrality and connectedness. Urban Stud 2000; 37: 2257-85.

[10] Hill RC, Fujita K. The nested city: introduction. Urban Stud 2003; 40: 207-17.

[11] Jacobs AJ. Developmental state planning, sub-national nestedness, and reflexive public policymaking: keys to employment growth in Saitama City, Japan. Cities 2008; 25: 1-20.

[12] Markusen A, Park, SO. The state as industrial locator and district builder: the case of Changwon, South Korea. Econ Geogra 1993; 69: 157-81.

[13] Park SO, Markusen A. Generalizing new industrial districts: a theoretical agenda and an application from non-Western economy. Environ Plann A 1995; 27: 81-104.

[14] Gallent N. Industrial park development and planning in South Korea. Reg Stud 1997; 31: 424-30.

[15] Hassink R. Towards regionally embedded innovation support systems in South Korea? Case studies from Kyongbuk-Taegu and Kyonggi. Urban Stud 2001; 38: 1373-95.

[16] Hill RC, Kim JW. Global cities and developmental states: New York, Tokyo, and Seoul. Urban Stud 2000; 37: 2167-95.

[17] Lee YS. Labor shock and the diversity of transnational corporate strategy in export processing zones. Growth Change 1999; 30: 337 65.

[18] Lee YS. Lean production systems, labor unions, and Greenfield locations of the Korean new auto assembly plants and their suppliers. Econ Geogra 2003; 79: 321-39.

[19] Jo HJ. A spatial change of R\&D function in auto suppliers located in Ulsan: focused on the concept of 'geograraphical proximity'. Korean J Soc 2006; 40: 207-32.

[20] Jo HJ, You JS. Transferring production systems: an institutionalist account of Hyundai motor company in the United States. J East Asian Stud 2011; 11: 41-73.

[21] Bae Y, Sellers J. Globalization, the developmental state and the politics of urban growth in Korea: a multilevel analysis. Int Urban Reg Res 2007; 31: 543-60.

[22] Cho M, Hassink R. Limits to locking-out through restructuring: the textile industry in Daegu, South Korea. Reg Stud 2009; 43: 118398.

[23] Kim WB. Repositioning of city-regions: Korea after the crisis. In: Scott AJ, Ed. Global city-regions: Trends, theory, policy. New York: Oxford University Press 2001; pp. 263-84.

[24] Park BG. Politics of scale and globalization of the South Korean automobile industry. Econ Geogra 2003; 79: 173-94.
[25] Park BG. The territorial politics of regulation under state capitalism: Regional parties and the politics of local economic development in South Korea. Space Polity 2005; 9: 237-59.

[26] Park BG. Uneven development, inter-scalar tensions and the politics of decentralization in South Korea. Int Urban Reg Res 2008; 32: 40-59.

[27] Lee YS. Balanced development in globalizing regional Development? Unpacking the new regional policy of South Korea. Reg Stud 2009; 43: 353-67.

[28] KOSIS. Korean statistical information service database. Daejeon: statistics Korea. Retrieved on October 10, 2010. Available from: http://www.kosis.kr

[29] Seoul is classified as a Teukbyeol-si or Special City. The number of Gwangyeok-si was expected to increase to seven in the future with 1 July 2010 amalgamation of the cities of Changwon, Masan and Jinhae, to create a new Changwon city of 1.08 million. Dong-A Ilbo. Report. 3-City Merger to Produce $\$ 660 \mathrm{Mln}$ in Benefits. The Dong-A Ilbo. [serial on internet]. October 8, 2009. [Retrieved October 9, 2010]. Available from http://english.donga.com/srv/ service.php3?biid=2009100875308

[30] Ulsan Metropolitan City [homepage on the Internet]. Ulsan: Ulsan Statistical Office. Online Retrieved on November 18, 2010 Available from http://english.ulsan.go.kr

[31] US EIA. Country analysis briefs: South Korea energy data, statistics and analysis - oil, gas, electricity, coal. Washington DC: US Energy Information Administration 2010.

[32] IPA Invest Korea: Ulsan for you. Seoul: Korean National Investment Promotion Agency. Online. Retrieved on September 25, 2010. Available from http://ulsan.investkorea.org. Also see Ulsan Fine Chemical Industry Center. Online. Retrieved on October 1, 2011. Available from http://english.ufic.or.kr

[33] Park HS, Rene E, Choi SM, Chiu A. Strategies for sustainable development of industrial park in Ulsan, South Korea - From spontaneous evolution to systematic expansion of industrial symbiosis. J Environ Man 2008; 87: 1-13.

[34] Evans P. Embedded autonomy: states \& industrial transformation. Princeton, NJ: Princeton University Press 1995.

[35] Bello W, Rosenfeld S. Dragons in distress: Asia's miracle economies in crisis. San Francisco: Institute for Food and Development Policy 1990, [especially quote on p. 129].

[36] Lee YH. The failure of the weak state in economic liberalization: liberalization, democratization and the financial crisis in South Korea. Pac Rev 2000; 13: 115-31.

[37] Pirie I. The Korean developmental state: From dirigisme to neoliberalism. New York: Routledge 2008.

[38] Kim JG. Assessment of recent industrialization in wetlands near Ulsan, Korea. J Paleolimol 2005; 33: 433-44.

[39] Chung KH. Industrial progress in South Korea. Asian Surv 1974; 14: 439-55.

[40] Heo UK, Roehrig T. South Korea since 1980. New York: Cambridge University Press 2010 .

[41] SK Energy. Tomorrow's energy: in progress. 2009 annual report. Seoul: SK Energy 2010.

[42] Cumings B. Korea's place in the sun. A modern history. New York: WW Norton 2005. [especially see quote cited later on page 324].

[43] Stern J, Kim JB, Perkins D, Yoo JH. Industrialization and the state: The Korean heavy and chemical industry drive. Cambridge, MA: Harvard 1995. [especially see later quote on p.144].

[44] Auty R. The impact of heavy-industry growth poles on South Korean spatial structure. Geoforum 1990; 2: 23-33.

[45] Leipziger D, Petri P. Korean industrial policy: Legacies of the past and present. In: Cho LJ, Kim YH, Eds. Korea's political economy: an institutional approach. Boulder, CO, USA: Westview Press 1994; pp. 581-619. See quote on p. 592.

[46] Kirk D. Korean Dynasty: Hyundai and Chung Ju Yung. Armonk, NY: M.E. Sharpe 1994. [especially later quote on p. 145].

[47] Lansbury R, Kown S, Suh CS. Globalization and employment relations in the Korean auto industry: The case of the Hyundai motor company of Korea, Canada, and India. Asian Pac Bus Rev 2006; 12: 131-47.

[48] Amsden A. Asia's next giant: South Korea and late industrialization. New York: Oxford University Press 1994.

[49] Watanabe M. Korea: Protection and regulation in the automotive industry. In: Inoue R, Kohama H, Urata S, Eds. Industrial policy in East Asia. Tokyo: JETRO 1993; pp. 229-46. 
[50] OICA. World motor vehicle production: World ranking of manufacturers, 1998-2009. Paris: International Organization of Motor Vehicle Manufacturers 1999-2010.

[51] KMC 2009 Annual report. Kia Motors Corporation, Seoul 2010.

[52] HyMC. Hyundai Worldwide. Seoul: Hyundai Motor Company. Retrieved on October 2, 2011. Available from: http://worldwide. hyundai.com/hyundai-worldwide.html. Also see: HyMC. Hyundai Profile: Hyundai Manufacturing. Seoul: Hyundai Motor Company. Retrieved on October 2, 2011. Available from: http://worldwide. hyundai.com/company-overview/profile/ manufacturing.html; and HyMC. Hyundai: from...to.... 2009 annual report: Seoul: Hyundai Motor Company 2010.

[53] Park GH. Economic and social networks: Impacts on regional economic outcomes and concentrations. Unpublished dissertation. Cleveland: Cleveland State University 2009.

[54] HyHI. Hyundai Heavy Industries: Shipbuilding. Ulsan: Hyundai Heavy Industries. Retrieved on September 23, 2010. Available from: http://english.hhi.co.kr/Business/ Shipbuilding.asp

[55] Dicken P. Global shift: Mapping the changing contours of the world economy. $5^{\text {th }}$ ed. New York: Guilford Press 2007. [especially quoted materials on $\mathrm{p} 303$ and 385 , respectively].

[56] KMC. Kia Motors: Global Network. Seoul: Kia Motors Corporation. Retrieved on October 2, 2011. Available from: http://www.kia motors.com/about-kia/global-organization/default.aspx

[57] Ward's. US light vehicle sales by company December 2010. Detroit: Ward's Communications. Retrieved on January 8, 2011. Available from: http://www.wardsauto.com.

[58] Ramstad E. Japan, South Korea tussle over won. Wall Street Journal [serial on internet]. October 14, 2010. Retrieved on December 31, 2010. Available from: http://online.wsj.com

[59] Sunoo HK. Korea: a political history in modern times. Columbia, MO: Korean-American Cultural Foundation 1970.

[60] McNamara D. The colonial origins of Korean enterprise, 19101945. New York: Cambridge University Press 1990.

[61] Eckert C. Offspring of empire: The Koch'ang Kims \& the colonial origins of Korean capitalism 1876-1945. Seattle: University of Washington Press 1991.

[62] Kohli A. State-directed development: political power and industrialization in the global periphery. New York: Cambridge University Press 2004.

[63] Hill RC, Lee YJ. Japanese multinationals and East Asian development: The case of the auto industry. In Sklair L Ed. Capitalism and development. New York: Routledge 1994; pp. 289315 ; [especially quote on p. 304].
[64] MMC. Mitsubishi motors, about us. Tokyo: MMC. Retrieved on November 4, 2010. Available from: http://www.mitsubishimotors.com

[65] Marshall A. Industry and trade. New York: Macmillan 1919.

[66] Jacobs J. Cities and the wealth of nations. New York: Random House 1984.

[67] Isard W. Location and space-economy. New York: John Wiley \& Sons 1956.

[68] Scott AJ, Storper M. Regions, globalization, development. Reg Stud 2003; 37: 579-93.

[69] According to B. S. Lee et al.'s econometrics model of 10 cities, growth dynamics in South Korea's industrial districts were consistent with the Marshall and Jane Jacobs' industrial districts theory. See Lee BS, Kim S, Hong SH. Sectoral manufacturing productivity growth in Korean regions. Urban Stud 2005; 42: 120119.

[70] Changwon-si [homepage on the Internet]. Changwon. Retrieved on September 29, 2011. Available from http://eng.changwon.go.kr/j $\mathrm{sp} / \mathrm{main} / \mathrm{main} . j \mathrm{sp}$

[71] Do JH. Ulsan Globalizing Earthenware Tradition. Korea Times [serial on internet]. July 13, 2009. Retrieved on September 23, 2010. Available from: http://www.koreatimes.co.kr/www/news/ nation/2009/10/281_48378.html

[72] Since most financial figures included were from 2008, the July 1 , 2008 exchange rate on of $1,048.11 \mathrm{KRW}$ to $\$ 1$ US was used for all monetary figures included in the text (See http://www.oanda.com).

[73] Lee HS. Ulsan Posts Largest Per-Capita GDP. Korea Times [serial on internet]. December 12, 2009. Retrieved November 23, 2010). Available from: http://koreatimes.co.kr/www/news/biz/2009/12/ 123_57724.html

[74] BMI. South Korea: Petrochemicals annual report. Business Monitor Int'l, London 2010.

[75] Min I. Taehwa river art fest to return in October. Korea Times. [serial on internet]. September 24, 2010 Retrieved on September 24, 2010. Available from: http//www.koreatimes. co.kr/www/news/ art/2010/09/135_73426.html

[76] Gyeongsangnam-do [homepage on the Internet]. Changwon: South Gyeongsang Province Online. Retrieved on November 18, 2010. Available from http://english.gsnd.net/

[77] Gyeongsangbuk-do [homepage on the Internet]. Daegu: North Gyeongsang Province. Online. Retrieved on November 18, 2010. Available from http://www.gb.go.kr/eng/main/main.jsp

(C) A.J. Jacobs; Licensee Bentham Open .

This is an open access article licensed under the terms of the Creative Commons Attribution Non-Commercial License (http://creativecommons.org/licenses/by$\mathrm{nc} / 3.0 /$ ) which permits unrestricted, non-commercial use, distribution and reproduction in any medium, provided the work is properly cited. 